\title{
The Implementation of Higher-Order Thinking Skills in EFL Classroom: Teachers' Perceptions
}

\author{
Fajar Dwi Utami ${ }^{*}$, Joko Nurkamto ${ }^{1}$, Sri Marmanto ${ }^{1}$ and Lita Liviani Taopan ${ }^{1}$ \\ ${ }^{1}$ Graduate School of English Education, Sebelas Maret University, Indonesia
}

\begin{abstract}
Higher-Order Thinking Skills (HOTS) is inevitably important to develop students' critical thinking as well as creative thinking skills in 21 st century era. In the current curriculum of Indonesia, called 2013 curriculum, the government tries to promote the development of students' critical and creative thinking by applying HOTS-based teaching in the classroom. In fact, when conducting teaching learning process, teachers are directly or indirectly influenced by their perceptions about HOTS itself. To reveal their perceptions, this study aims to investigate English teachers' perceptions on HOTS implementation in Indonesia context. The subject of this survey is 28 pre-service and 10 in-service English teachers in high school level in Indonesia. There are four areas of HOTS perceptions that are investigated in this study namely teachers' perceptions on planning, teachers' perceptions on implementing, teachers' perceptions on assessing and teachers' perceptions on responsibility towards HOTS teaching learning activities. The result shows that in the areas of planning, implementing, and assessing, pre-service teachers show more positive result than inservice teachers. On the other hand, in the area of responsibility, in-service teachers show more positive result than pre-service teachers.
\end{abstract}

Keywords: HOTS, Implementation, EFL Classroom, Teachers' Perceptions

\section{Introduction}

Inevitable prompt growth in $21^{\text {st }}$ century influences almost every aspect of human life (Assare, Mohammadi, Forutan, \& Salehizadeh, 2016) and there is no exception for education aspect. The needs of much improved competencies and skills are required to equip students of any level of education in today's globalization and disruption era (Huang et al., 2010). Skills and competencies that are needed in nowadays era as stated in Partnership and Learning Framework (P21) (2015) are generally known as 4Cs competencies consist of the competency of critical thinking and problem solving, communication, collaboration, and creativity and innovation. Those four aspects are urgently required and need to be taught to students, especially the critical thinking and problem solving competencies. Due to its importance, critical thinking skills should be infused into students' daily instructions to decently make them ready to for school assessments, rigorous college expectations, employers' demands, and complex life situations. In fact, by equipping them with critical thinking skills, teachers make them enable to reason effectively, make rational judgments and decision, and solve problems (Stobaugh, 2013).

To meet the $21^{\text {st }}$ century skills of students, namely critical thinking and creative thinking skills to solve problems, Indonesia government has been facilitating higher-order thinking skills, through the 2013 curriculum, as the base of teaching including teaching in EFL classroom. Not only in Indonesia, in the current decades, Higher-Order Thinking Skills (HOTS) has become the center of attention of some countries in the world to build their generation to be critical thinkers who are ready to face the real life situation in this era. Seng in 1998 proposed the teaching of thinking skills among pre-service and in-service teachers in Singapore. In China, Wang and Farmer (2008) studied adults' instructors Higher-Order Thinking Skills (HOTS) by using a survey instrument called Low Order Thinking Skills and High Order Thinking Skills (LOTSHOTS) instrument. The study showed that mostly the adults' instructors used to teach in the level of Low Order Thinking Skills (LOTS) that includes knowledge, comprehension, and application rather than in the level of Higher-Order Thinking Skills (HOTS). Adeyemi (2012) examined the critical thinking in Nigeria. The study examined how the students can be engaged in an environment that develop them to be critical thinkers and problem solvers. In addition, all 
the phenomena of applying Higher-Order Thinking Skills (HOTS) are intended to foster the critical thinking of students. In addition, most countries in the world give a tremendous attention towards the implementation of those HOTS-based teaching learning. They are in search of the best strategies to make the better generation with the better reasoning and critical thinking competencies.

In Indonesia, the attention towards the implementation of HOTS in senior high school and vocational high school increases rapidly since the current curriculum that is applied in Indonesia, 2013 curriculum (K-13), has the tendency on promoting higher-order thinking skills in the classroom. By applying 2013 curriculum (K-13) that is a HOTS-based teaching learning process, government expects students to achieve competencies that are required in the $21^{\text {st }}$ century. In addition, empowering students with higher-order thinking skills is coherent with the discourse of improving the education quality through the outcomes of the learning process (Kuswana, 2011). Obviously, the improvement of education quality and successful teaching learning process are expected. Ramdiah et al. (2019) believed that the successful teaching learning process can be indicated by a set of knowledge, attitude and skills.

In contrast, the implementation of Higher-Order Thinking Skills (HOTS) is still far from perfection. The challenges are there to be transformed into the opportunities. Not only in Indonesia but also in some countries, for example Malaysia, the implementation of HOTS still faces some challenges. In a study conducted in Malaysia classroom, there found that the study indicates that majority of the students who have learnt knowledge that used HOTS base, still could not transfer the knowledge they have learnt into the outside classroom context (Seman, Yusoff, \& Embong, 2017). Another study highlighted the challenges that are faced by the mathematic teachers in Malaysia. The study was conducted by involving 160 mathematic teachers in Johor state. All participants are asked about their difficulties in teaching Higher-Order Thinking Skills (HOTS) (Alhassora, Abu, \& Abdullah, 2017). Furthermore, a study conducted by American Colleges and Universities found that there is a lack of importance in pre-service teachers' training methodology in helping enhance Higher-Order Thinking Skills (HOTS). The teacher-training centers face some challenges on how to systematically teach it to them. The implementation of Higher-Order Thinking Skills (HOTS) are also studied by Abdul Aziz Ahmad, Ismail, Ibrahim, and Samat (2017) in L2 classroom. The findings show that the implementation of HOTS in the L2 classroom is quite limited and it is influenced by many various factors, particularly those that are related to students, pedagogical and institutional factors. The study suggests that there need more improvement involving teachers and the students.

Those challenges possibly raise a major question, why those phenomena can occur. It is believed that there are some factors that influence the effective teaching learning process. Studies revealed that teacher was one of the main factors that influenced success or failure in teaching for HOTS (Seman et al., 2017). Thus, the role of teachers is obviously essential. Every action taken by teachers will determine whether the teaching is successful or not. In fact, teachers' actions cannot be separated from their perceptions that are the ways they perceive and see everything.

The previous study attempted to unveil the perceptions of science pre-service teachers in the implementation of HOTS. The study was conducted in Pontianak, Indonesia, and uncovered pre-service teachers' perceptions about the importance of Higher-Order Thinking Skills (HOTS) and Higher-Order Thinking Skills (HOTS) they needed to become teachers in the $21^{\text {st }}$ century. It also suggested that the awareness of the importance of High Order Thinking Skills (HOTS) should be fostered during pre-service education (Afandi, Sajidan, Akhyar, \& Suryani, 2018a). Kurniati and Mursyid (2017) conducted a study in Cianjur, Indonesia, that unveiled the teachers' perspective towards the practice of Higher-Order Thinking Skills (HOTS) in EFL classrooms, its application, assessment and constraints. The study involved six teachers and the study suggested that the professional teachers needed to enhance their quality in implementing HOTS in EFL classrooms. However, none of the previous studies investigated pre-service and in-service English teachers' perceptions in the area of planning, implementing, assessing and responsibility in the implementation of HOTS in high school level. 
Therefore, further study is required to be conducted. The aim of this study is to investigate and describe preservice and in-service English teachers' perceptions on the implementation of Higher-Order Thinking Skills (HOTS) that cover the area of planning, implementing, assessing, and responsibility. The findings from this study can be the evaluation and reflection of the current practice of HOTS especially in English as a foreign language classroom so that the implementation of HOTS can be improved in the near future. In addition, it will provide a basic data for stakeholders and policy makers that can be taken as considerations when they are going to make any policy in education.

\section{Literature Review}

\section{Perception}

It is generally believed that the perceptions possessed by teachers are formed by their schemata and life experiences that cover the tradition, educational background, and culture. All of those aspects contribute on how teachers view things from their lenses. Cutting (in Ardini, 2018) assumed that perception in general is dealing with collecting information about the world by means of the senses. In addition, the concept of perception and interpretation is the combination of what the pre-services and in-service English teachers believe and know, what is happening in their mind when they perceived the stimulus and what they describe regarding to their interpretation. Furthermore, this study examines pre-service and in-service English teachers' perceptions that are the thoughts or mental images teachers have about the implementation of Higher-Order Thinking Skills (HOTS) in EFL classrooms.

\section{Curriculum}

2013 curriculum is the most current curriculum that is applied in Indonesia. This curriculum goal is to shape the individuals who are faithful in God, build good characters, confident, successful in learning, responsible citizens and positive contributors to the civilization (Ministry of Education and Culture in Ahmad, 2014). In addition, through the implementation of 2013 curriculum, government expects students to achieve competencies in $21 \mathrm{st}$ century by implementing Higher-Order Thinking Skills (HOTS) namely critical thinking, creativity, innovation, confidence and collaboration. Those five competencies are the targets that require to be achieved. This curriculum is in line with the policy that is made by Ministry of Culture and Education as an effort to improve the quality of students. In 2018, 2013 curriculum has been integrated with the character building and HOTSbased teaching learning process (Ariyana, Pudjiastuti, Bestary, \& Zamroni, 2018).

\section{Higher-Order Thinking Skills (HOTS)}

Higher-Order Thinking Skills (HOTS) is a complex thinking process involving elaboration, drawing conclusion, developing representation, analysis, and developing relationship that involves basic mental activities (Resnick, 1987). The current taxonomy used is the revised version of Bloom's taxonomy by Anderson et al. (2001). The taxonomy serves as guidelines to map the students' cognitive domain. In the taxonomy Lower-Order Thinking Skills (LOTS) cover C1, C2, and C3 that are the skills of remembering, understanding and applying while Higher-Order Thinking Skills cover those C4, C5, and C6 domain that are the skills of analyzing, evaluating, and creating (Anderson et al., 2001).

In addition, there have been a number of studies that were conducted regarding to teachers' perceptions, knowledge and perspectives regarding HOTS (Afandi, Sajidan, Akhyar, \& Suryani, 2018b; A. Ahmad, Ismail, Ibrahim, \& Samat, 2017; Kurniati \& Mursyid, 2017; Retnawati, Djidu, Apino, \& Anazifa, 2017). However, the studies previously conducted mostly emphasize on the area of science or mathematics subject in senior high school level. To fill the gap, this research aims to reveal the teachers' perceptions regarding HOTS in the area of English subject. Furthermore, the subjects of the current study are not only in-service teachers but also pre- 
service teachers. Finally, teachers' perceptions that are covered are the perceptions in the area of planning, implementing, assessing, and teachers' responsibility.

\section{The Aim of Research}

Based on the background description, this study aims to investigate pre-service and in-service English teachers' perceptions of the implementation of Higher-Order Thinking Skills (HOTS) in EFL classrooms. The perceptions investigated in the current study consist of some areas that are the teachers' perceptions regarding planning, implementing, assessing, and teachers' responsibility.

\section{Research Methodology}

This is a qualitative study that provides information about facts and description about pre-service and in-service English teachers' perceptions on the implementation of Higher-Order Thinking Skills (HOTS) in EFL classrooms. The perceptions cover four areas that are the perceptions on planning, implementing, assessing, and responsibility. The population in this study is pre-service and in-service teachers in Madiun, Indonesia. This study make uses purposive sampling based on some criteria. The first criteria, the participant must be an English pre-service or in-service teacher and have taught in a senior high school or vocational high school. The second criteria, the participant must have experiences in applying Higher-Order Thinking Skills (HOTS) that is suggested by 2013 curriculum (K-13). The samples of this current study are 38 English teachers that consist of 28 pre-service teachers and 10 in-service teachers.

The data in this study are obtained from questionnaire and semi-structured interview. The questionnaire consists of main 2 sections. The first section is participant's basic information and the second is the perceptions of Higher-Order Thinking Skills (HOTS) implementation that is divided into 4 areas namely planning, implementing, assessing and responsibility. The questionnaire that is used in the second section is an adaptation from Rajendran (2001) and Aziz et al. (2017). The questionnaire and interview results are used to investigate pre-service and in-service English teachers' perceptions on the implementation of Higher-Order Thinking Skills (HOTS) in the English as a foreign language (EFL) classroom.

\section{Findings}

In this section, the data that were obtained from the participants through questionnaire will be displayed. The following is the result of Pre-service and In-service English Teachers' Perceptions of the implementation of HOTS in EFL classrooms. 

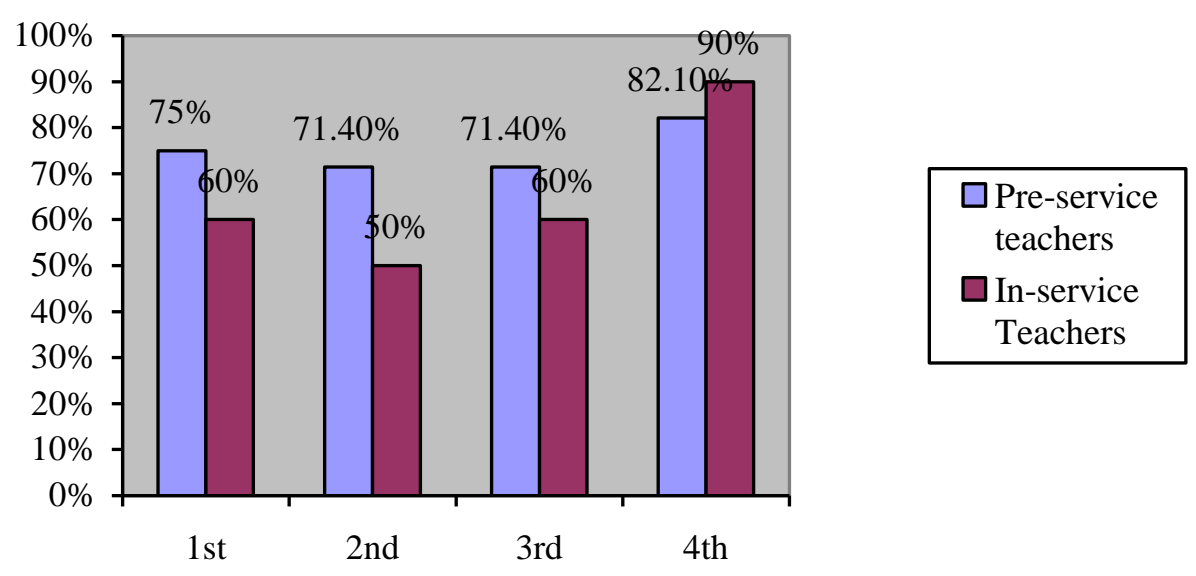

Table 1. The result of Pre-service and In-service English Teachers perceptions of the implementation of HigherOrder Thinking Skills (HOTS)

The survey was conducted by employing 13 questionnaire items that are divided into 4 areas. The first area covers four items about pre-service and in-service teachers' perceptions on planning the classroom teaching learning that is based on the Higher-Order Thinking Skills (HOTS). The second area includes four items related to their perceptions on the implementation of the first planning. The third area contains two items related to their perceptions on assessing of the Higher-Order Thinking Skills (HOTS) of the students. The fourth area covers three items about their perceptions on responsibility that is related to the implementation of Higher-Order Thinking Skills (HOTS).

The table shows the result of each area both in pre-service and in-service teachers' perceptions. The first area that is about their perception in planning a teaching learning process shows that pre-service teachers have more positive perceptions as high as $75 \%$ compared to the in-service teacher perceptions that is $60 \%$. The second area shows that the pre-service teachers have more positive perceptions on the matter of implementing what they have planned to teach in the classroom. The pre-service teacher perception in the second section is as high as $71.4 \%$ while the in-service teachers' perceptions percentage is $50 \%$. The third area shows that in the perceptions of assessing the students Higher-Order Thinking Skills (HOTS), the more positive perceptions are shown by the pre-service teachers whose perception percentage is $71.4 \%$ compared to in-service teachers' perceptions whose perceptions percentage is $60 \%$. The fourth area displays that pre-service teachers' perceptions is as high as 82,1 $\%$ and in-service teachers' percentage is $90 \%$ in the perceptions of responsibility related to the teaching HigherOrder Thinking Skills (HOTS) in the classroom. It means that in this section, the in-service teachers perceive more positively in their perceptions of responsibility.

\section{Discussion}

The perceptions of teachers are very important matter in teaching learning process as their perceptions will be reflected on every action they take in the classroom. Thus, investigating their perception is essential and required to improve the effectiveness of teaching English as a foreign language in the classroom. The following is the discussion of the perceptions results of pre-service and in-service teachers' on the implementation of Higher-Order Thinking Skills (HOTS).

\section{Perceptions on the Planning}

Planning a lesson is not as easy as it seems, it is not only a mental checklist, but it is more into detailed lesson that is based on a prescribed format (Fauziati, 2017). A teacher may have his own style in planning a lesson, but 
it still has to stick with the curriculum standards. All the material and content developed by teachers should meet the standards. The needs of the students are also a big consideration to take when teachers begin planning a lesson. Thus, planning is quite essential in teaching learning process. In the implementation of 2013 curriculum (K-13), teachers are expected to be able to plan a lesson that is based on the Higher-Order Thinking Skills (HOTS) that is intended mainly to develop students' critical thinking. It is supported by Kurniati and Mursyid (2017) that teaching English in English as a foreign language setting apparently requires the teachers to possess expertise in planning learning activities that would develop students thinking skills. The perceptions of preservice teachers are positive in four items that are given to them. The items cover whether they know the details of the 2013 curriculum (K-13) that focuses on building Higher-Order Thinking Skills (HOTS), whether they are able to plan a HOTS-based lesson plan in English as a foreign language classroom, whether they are able to use resource materials for effective learning of Higher-Order Thinking Skills (HOTS), and whether they are able to stratify the learning components to the level of the students' Higher-Order Thinking Skills (HOTS). On those four items the highest positive perceptions is on the ability to use resource materials for effective teaching learning in the classroom. Most of the pre-service teachers argues that in this matter they are quite able as they have been taught to not only use the provided learning material resources but also use the supplementary learning material resources that are obtained from text books, internet, and develop their own learning material resources that fit to the students' needs. Some of the pre-service teachers especially those who teach vocational high schools students, they provide supplementary or additional learning material as the curriculum in English subject for those senior high school students and vocational high school students are the same. In fact, they had different needs in English subject. This later stimulates those vocational high school teachers to provide some material that can meet their students' needs. In in-service teachers' perceptions, the data shows that they also perceive positive perceptions although its percentage is lower than the percentage from the pre-service teachers. From four items provided to them, the lower percentage is in the item whether they are able to use resource materials for effective learning of High Order Thinking Skills (HOTS). When it is confirmed in an interview the participants perceiving negative perceptions believe that they lack of the internet access at their schools that limit them to develop learning resources.

\section{Perceptions on the Implementing}

The implementation is the action that is conducted based on the plan that has been made before. In this section, the perceptions of implementing Higher-Order Thinking Skills (HOTS) will be discussed. There are four items that are covered in this section namely whether they know how to use different strategies and techniques to teach Higher-Order Thinking Skills (HOTS) in a foreign language classroom, whether they are able to use different strategies and techniques to teach Higher-Order Thinking Skills (HOTS) in a foreign language classroom, whether they know how to involve students actively in the teaching and learning of Higher-Order Thinking Skills (HOTS) in a foreign language classroom, and whether they know how to develop individual potential of students' Higher-Order Thinking Skills (HOTS). The result shows that pre-service teachers gain more positive perceptions as high as $71.40 \%$ compared to the in-service teachers that gain as high as $50 \%$ of all. Both in pre-service and in-service teachers, the highest value is in the item whether they know how to involve students actively in the teaching and learning of Higher-Order Thinking Skills (HOTS) in a foreign language classroom. Some of pre-service teachers who have positive perceptions in this item argue that getting the students engaged in an active teaching learning process is not a hard thing to do since they apply what is called as a scientific approach that enables students to be the center of learning. In fact, it is coherent with the implementation of 2013 curriculum (K-13) where Higher-Order Thinking Skills (HOTS) is promoted. In addition, it is also supported by the Ministry of Education of Indonesia that believes that the successful teaching and learning process in 2013 curriculum (K-13) could be achieved through the implementation of scientific approach (Suharyadi in Ratnaningsih, 2017). They indicate that they applied the steps of scientific approach involving observing, questioning, gathering information or experimenting, associating or information processing, and communicating. At first, they find it difficult in the stages of questioning since students are used to be passive at class, but later they give more stimulation in observing stage. The lowest valued item in pre- 
service teachers is whether they know how to develop individual potential of students' Higher-Order Thinking Skills (HOTS). Most of them argue that they teach some classes in the schools that they have more than one class consisting about 25 students, so that sometimes it is quite difficult to analyze each individual potential of Higher-Order Thinking Skills (HOTS) and to facilitate each individual to develop.

\section{Perceptions on the Assessing}

Identifying the students' competencies in Higher-Order Thinking Skills (HOTS) can be conducted by employing assessment. As assessment aims to unveil the students' thinking skills is employed, the teachers' understanding about the students' learning and how they think should be improved (Brookhart, 2010). In the survey that was conducted, both pre-service and in-service teachers showed a high percentage in having positive value in this section. The pre-service teacher positive perceptions value is $71.4 \%$ while the in-service teacher value is $60 \%$. Although both of them showed high percentage, the pre-service teacher positive perception value is higher in this section. Both of pre-service and in-service teachers score the highest on the item whether they know how to evaluate students' HOTS improvement in the classroom. Based on the further interview with them, they feel confident that they know how to evaluate students' HOTS improvement since they have guidelines of composing assessment of HOTS whether orally or written. However, some claim that dealing with designing assessment to measure students' HOTS is not an easy thing to do. They tend to believe that HOTS items are those that have high difficulty level, in fact HOTS items do not always have high difficulty level instead they are the items that stimulate students into reasoning the answers. Thus, some of them are not confident about the assessment they make. It is coherent with what (McMillan, 2001) found in his study in secondary teachers that they believe they make classroom practices and assess Higher-Order Thinking Skills (HOTS) of the students, but actually they do not. Apparently, they only assess LOTS since they assume that those items are easy to make. Brookhart (2010) supported that the reason those test questions focusing in recalling level are so common is that they are the easiest to make.

\section{Perceptions on the Responsibility}

Teachers play important roles in developing the students Higher-Order Thinking Skills (HOTS). They take the responsibility to develop their own professionalism in order to provide the best teaching they can. In this section, all of the 38 pre-service and in-service teachers are assessed in the area of responsibility. The result shows that both of the pre-service and in-service teachers have high percentage. It means that they perceive that they have a big responsibility in developing students' Higher-Order Thinking Skills (HOTS). The percentage of pre-service teachers who have positive perception is $82.1 \%$ while the in-service teacher percentage is $90 \%$. The item that gets the highest percentage in both pre-service and in-service teachers is whether to be a better teacher one needs continuous training in the teaching of HOTS. They believe that the teaching and learning process is a dynamic process where it is influenced by some aspects such as curriculum, the development of technology, etc. Thus, to keep up to date with everything related to teaching learning is always needed. Today, the main focus of education in Indonesia is building Higher-Order Thinking Skills (HOTS) of the students so that they feel they need to continuously join some training that will broaden their knowledge and practices of implementing HOTS in classroom.

\section{Conclusion}

In the current study, the limitation should be noted is that the context is in Indonesia, more specifically in Madiun. The samples taken for the current study are 28 pre-service teachers and 10 in-service teachers who teach English in senior high school and vocational high school level. The findings of the current study indicate that the pre-service and in-service English teachers in senior high school and vocational high mostly have positive perceptions in four areas namely perceptions on planning, perceptions on implementing, perceptions in assessing, and perceptions in responsibility. In the area of planning, implementing and assessing, both of the 
pre-service and in-service teachers show positive perceptions, but pre-service teachers' percentage of positive perceptions is higher than in-service teachers' percentage of positive perceptions. In the area of responsibility the pre-service and in-service English teachers also show the positive perceptions, but in this area the in-service teachers' percentage is higher than the pre-service teachers' percentage. From all of this result, teachers positive perceptions towards the implementation of Higher-Order Thinking Skills (HOTS) will positively affect their performances in the teaching process in the classroom However, the implementation of Higher-Order Thinking Skills (HOTS) will offer some challenges and opportunities for both teachers and students that will need them all to improve to face all of those challenges and grab every opportunity. Further study should be conducted to investigate the level of Higher-Order Thinking Skills (HOTS) that are possessed by the students, students' perceptions towards the implementation of Higher-Order Thinking Skills (HOTS), and the strategies to support the success of Higher-Order Thinking Skills (HOTS) implementation in Indonesia, especially in Madiun.

\section{Acknowledgement}

The authors would like to express gratitude and appreciation to all parties who give encouragement and opportunity to complete the research. The authors gratefully acknowledge the full support received from Indonesia Endowment Fund for Education (LPDP). The authors also gratefully acknowledge the helpful comments and suggestions from the reviewers. Last but not least, the acknowledgement is also expressed to all participants who have voluntarily contributed to the research.

\section{References}

Abdul Aziz Ahmad, A., Ismail, F., Ibrahim, N. M., \& Samat, N. A. (2017). Investigating the Implementation of Higher Order Thinking Skills in Malaysian Classrooms: Insights from L2 Teaching Practices. Sains Humanika, 9(4-2), 65-73. https://doi.org/10.11113/sh.v9n4-2.1361

Adeyemi, S. B. (2012). Developing critical thinking skills in students: A mandate for higher education in Nigeria. European Journal of Educational Research, 1(2), 155-161. https://doi.org/10.12973/eu-jer.1.2.155

Afandi, A., Sajidan, S., Akhyar, M., \& Suryani, N. (2018a). Pre-Service Science Teachers' Perception About High Order Thinking Skills (HOTS) in the 21st Century. International Journal of Pedagogy and Teacher Education, 2(1), 107-114.

Afandi, Sajidan, Akhyar, M., \& Suryani, N. (2018b). Pre-Service Science Teachers Perception About High Order Thinking Skills (HOTs) in 21st Century, 2(1), 301-308.

Ahmad, A., Ismail, F., Ibrahim, N. M., \& Samat, N. A. (2017). Sains Humanika Investigating the Implementation of Higher Order Thinking Skills in Malaysian Classrooms: Insights from L2 Teaching Practices, 2, 65-73.

Ahmad, D. (2014). Understanding the 2013 Curriculum of English Teaching through the Teachers " and Policymakers "Perspectives, 2(4), 6-15.

Alhassora, N. S. A., Abu, M. S., \& Abdullah, A. H. (2017). Inculcating higher-order thinking skills in mathematics: Why is it so hard. Man in India, 97(13), 51-62.

Anderson, L., Krathwohl, D., Airasian, P., Cruikshank, K. A., Mayer, R. E., Pintrich, P. R., ... Wittrock, M. C. (2001). A Taxonomy for Learning,"Teaching, and Assessing-A Revision of Bloom's Taxonomy of Educational Objectives”,(Eds.) Addison Wesley Longman. New York.

Ardini, S. N. (2018). Teachers' Perception, Knowledge and Behaviour of Higher Order Thinking Skills (HOTS). ETERNAL (English Teaching Journal), 8(2).

Ariyana, Y., Pudjiastuti, A., Bestary, R., \& Zamroni. (2018). Buku Pegangan Pembelajaran Berorientasi pada Katerampilan Berpikir Tingkat Tinggi. Direktorat jenderal Guru dan Tenaga Kependidikan.

Assare, Mohammadi, Forutan, \& Salehizadeh. (2016). The Impact Of Globalization On Education. Journal of Administrative Management, Education, and Training, 12(5), 27-33. https://doi.org/10.25034/ijcua.2018.4707 
Aziz, A. A., Ismail, F., Ibrahim, N. M., \& Samat, N. A. (2017). Investigating the Implementation of Higher Order Thinking Skills in Malaysian Classrooms: Insights from L2 Teaching Practices. Sains Humanika, 9(4-2).

Brookhart, S. M. (2010). HOW TO ASSESS HIGHER-ORDER THINKING SKILLS IN YOUR CLASSROOM. Alexandria: ASCD.

Fauziati, E. (2017). Teaching English as a Foreign Language: Principle and Practice. Surakarta: Era Pustaka Utama.

Huang, D., Leon, S., Hodson, C., La Torre, D., Obregon, N., \& Rivera, G. (2010). Preparing Students for the 21st Century: Exploring the Effect of Afterschool Participation on Students' Collaboration Skills, Oral Communication Skills, and Self-Efficacy. CRESST Report 777. National Center for Research on Evaluation, Standards, and Student Testing (CRESST).

Kurniati, N., \& Mursyid. (2017). Exploring The Practice of High Order Thinking Skills Among English Teacher across Generation in EFL Classroom: A Case Study in Senior High Schools in Cianjur.

Kuswana, W. S. (2011). Taksonomi berpikir. Bandung: PT. Remaja Rosdakarya.

McMillan, J. H. (2001). Secondary teachers' classroom assessment and grading practices. Educational Measurement: Issues and Practice, 20(1), 20-32.

Partnership for 21st Century Skills (P21). (2015). Framework for 21st Century Learning.

Rajendran, N. (2001). The Teaching of Higher-Order Thinking Skills in Malaysia. Journal of Southeast Asian Education, 2(1), 42-65.

Ramdiah, S., Abidinsyah, Royani, M., \& Husamah. (2019). Understanding, Planning, and Implementation of HOTS by Senior High School Biology Teachers in Banjarmasin-Indonesia. International Journal of Instruction, 12(1), 425-440. Retrieved from www.e-iji.net

Ratnaningsih, S. (2017). Scientific Approach of 2013 Curriculum: Teachers Implementation in English Language Teaching. English Review: Journal of English Education, 6(1), 33. https://doi.org/10.25134/erjee.v6i1.768

Resnick, L. B. (1987). Education and Learning to Think. Whasington, D.C: National Academy Press. Retrieved from http://www.nap.edu.

Retnawati, H., Djidu, H., Apino, E., \& Anazifa, R. D. (2017). TEACHERS ' KNOWLEDGE ABOUT HIGHER-ORDER THINKING SKILLS AND. Problems of Education in the 21st Century, 76(2), 215-230.

Seman, S. C., Yusoff, W. M. W., \& Embong, R. (2017). Teachers challenges in teaching and learning for higher order thinking skills (HOTS) in primary school. International Journal of Asian Social Science, 7(7), 534-545.

Seng, S. (1998). Teaching Thinking Skills for Pre-Service and In-Service Teachers in Singapore. Paper Presented at the International Conference on Critical Thinking and Educational Reform (Zamboanga, Philippines, 1-7.

Stobaugh, R. (2013). Assessing critical thinking in middle and high schools: Meeting the Common Core. Routledge.

Wang, V., \& Farmer, L. (2008). Adult Teaching Methods in China and Bloom's Taxonomy. International for the Scholarship of Teaching and Learning, 2(2), 0-15. https://doi.org/10.20429/ijsotl.2008.020213 